$=$

\title{
The Impact of Interest Rate Changes by Federal Reserve on Turkey
}

Federal Rezerv'in Yaptı̆ı̆ Faiz Oranı Değişikliklerinin Türkiye Üzerine Etkisi

\author{
King BANAIAN $^{1}$ - Mustafa Göktuğ KAYA ${ }^{2}$ - Orhan Kemal KAPLAN ${ }^{3}$
}

\begin{abstract}
Central banks play an important role in the direction of capital flows through the interest rate channel. Capital flows also impact the exchange rate, which are important goals of monetary policy. Due to the prominence of the U.S. Dollar in international trade, decisions made by the Federal Reserve Bank (FED) also affect the decisions of Central Banks of other countries. During the 2008 financial crisis the FED reached the zero-bound of its policy rate (the federal funds rate) and engaged in quantitative easing. This lead to capital outflows from developing countries, who then raised interest rates defensively to protect their economies from adverse effects in their terms of trade.

This study examines the relationship between interest rates, effective exchange rates and growth by means of Granger Causality test, as a result of interest rates determined by FED in post-2003 period, in the direction of the interest rate Central Bank of the Republic of Turkey (CBRT/TCMB) applies to Dollar deposits. Turkey is a country that floats its exchange rate but protects against large movements. According to analysis results, the decisions made by CBRT are affected by FED interest rate changes. On the other hand, it was concluded that there was not any effect of CBRT interest rates on the exchange rate, consistent with its floating regime.
\end{abstract}

Keywords: Central Banking, Interest, CBRT, Financial Liberalization, Exchange Rate, Granger Causality. JEL Classification: E42, E43, E52, E58, E63

\begin{abstract}
ÖZET
Merkez bankaları faiz oranı kanalından sermaye akımları yönünde önemli bir rol oynamaktadır. Sermaye akımları, para politikasının önemli hedefleri olan döviz kurunu da etkiler. ABD Doları'nın uluslararası ticarette öne çıkması nedeniyle, Federal Rezerv Bankası (FED) tarafından alınan kararlar, diğer ülkelerin Merkez Bankalarının kararlarını da etkilemektedir. 2008 mali krizi sırasında FED, politika faizini (federal fonlar oranı) sıfır sınırına ulaştırdı ve niceliksel genişleme yaptı. Bu durum, gelişmekte olan ülkelerden sermaye çıkışlarına yol açmakta ve bu da ekonomilerini diş ticaret hadlerindeki olumsuz etkilerden korumak için faiz oranlarını defalarca artırmaktadır.

$\mathrm{Bu}$ çalışma, 2003 sonrası dönemde FED tarafından belirlenen faiz oranları sonucunda, Türkiye Cumhuriyet Merkez Bankası faiz oranı doğrultusunda dolar mevduatları faiz oranları, efektif döviz kurları ve büyüme arasındaki ilişkiyi Granger Nedensellik testi ile incelemektedir. Türkiye, dalgalı döviz kurunu sahip ancak büyük hareketlere karşı koruyan bir ülkedir. Analiz sonuçlarına göre TCMB tarafından alınan kararlar FED faiz oranındaki değişikliklerden etkilenmektedir. Öte yandan, dalgalı rejime paralel olarak TCMB faiz oranlarının döviz kuru üzerinde etkisi olmadığı sonucuna varılmıştır.
\end{abstract}

Anahtar Kelimeler: Merkez Bankacılığı, Faiz, TCMB, Finansal Serbestleşme, Döviz Kuru, Granger Nedensellik.

\footnotetext{
${ }^{1}$ Professor of Economics, Dean of School of Public Affairs, Saint Cloud State University, 720 4th Ave S., St. Cloud, Minnesota, USA. Phone: (320) 308-4790; Fax: (320) 308-4791; Email: kbanaian@ stcloudstate.edu, ORCID ID: 0000-0003-1044-6930

${ }^{2}$ Dr. , Visiting Scholar, Department of Economics, Saint Cloud State University, 720 4th Ave S., St. Cloud, Minnesota, USA. Phone: (320) 308-2227; Fax: (320) 308-2228; Email: mustafa.kaya@ @tcloudstate.edu, ORCID ID: 0000-0003-4124-4733

${ }^{3}$ Graduate Student, Institute of Social Sciences, Department of Economics, Zonguldak Bülent Ecevit University, Obesity and Diabetes Research Centre Building Floor:1 67100 , Zonguldak, Turkey, Phone: +90 (531) 9342270, Fax: +90 (372) 291- 2447, Email: orhankkaplan@gmail.com, ORCID ID: 0000-0002-6352-0543
} 


\section{INTRODUCTION}

Financial markets, together with globalization, are increasingly integrated into both domestic and foreign markets. Together with the increasing integration, the developments occurring in these markets effect the other markets via one or more channels. The most important one of these channels is the asset price channel (Ehrmann et al., 2011: 949-950). Capital movements that were limited until 1970s gained acceleration together with globalization after the end of the Bretton Woods system ${ }^{4}$. Together with globalization, capital outflows to the developing countries increased after 1970. In the debt crisis experienced after 1980, this case reversed but an excessive decrease did not occur in capital outflows from US to Asian and Latin American countries (McLean and Shrestha, 2002: 3).

In the last thirty years, increasingly liberal capital accounts led to new developments. All economic actors were in favor of this financial globalization (Schmukler, 2004: 41). Together with the global trade it brings, central banks were mostly responsible for both domestic and foreign policies that promoted financial liberalization and the management of the business cycle (Gediz and Sağın, 2015: 97). However there has been less consideration of the impact of central banks of world leaders like the Federal Reserve System of the United States (FED), the European Central Bank (ECB), the Bank of Japan (BOJ) and others on fluctuations in the developing countries. But it is well-known that developments of the FED or ECB will affect economic growth together with capital accumulation in those other countries (Fukuda, 2017: 1014).

U.S. monetary policy pushed investors in recovery period after the 2008 crisis to seek risk assets across the world including high interest rates in developing and middle-income countries. Leading to capital going to the developing countries.

After the Global Financial Crisis of 2008 the Fed abundantly issued money and expanded its economy. FED chair Ben Bernanke recognized this impact in a speech in 2013:

"Because many emerging market economies have financial sectors that are small or less developed by global standards but open to foreign investors, they may perceive themselves to be vulnerable to asset bubbles and financial imbalances caused by heavy and volatile capital inflows, including those arising from low interest rates in the advanced economies." (Bernanke, 2013)

Eventually the FED wanted to unwind its balance sheet and began to do so in October 2017. The inflows of the previous 7 years began to reverse.

High interest rates generally draw additional savings attention as a price for savers in exchange of saving they lend (P1çak, 2012: 62). In capitalist system, it is defined as a share capital receives in functional income distribution (Seyidoğlu, 2012: 22). One country's central bank that reacted to the reversal was the Central Bank of Turkish Republic (CBRT/TCMB). After rates had remained around $15-16 \%$ before the GFC, rates fell to as low as $1.5 \%$ with a combination of combating its own recession and the flow of 'hot money' into the economy. Lower interest rates encouraged borrowing; household debt as a share of disposable income rose from 39\% in 2008 to over 50\% by 2013 (Akcay and Gungen, 2019: 8). From 2014-17 the CBRT borrowing rate remained steady at $7.25 \%$ while the spread between the borrowing and lending rates compressed to as little as $1 \%$. Quantitative tightening by the FED collapsed demand for Turkish assets, which fell $96 \%$ in the first half of 2018. By June CBRT had to act after the dollar-lira exchange rate slid from 3.75 in January to 4.5 by the end of May. On June 1 it raised its interest rate from $7.25 \%$ to $15 \%$, and then two later hikes took the rate to $22 \%$ by mid-September. The economy subsequently fell into recession.

We therefore see that interest rate decisions made by the Federal Reserve Bank have important effects on the developing countries such as Turkey. In this paper we use the technique of Granger causality

\footnotetext{
${ }^{4}$ Together with the emergence of flexible exchange rate system after Bretton Woods, the important developments were experienced in capital mobility and capital mobility was encouraged in all countries (Obstfeld and Taylor, 2003: 133).
} 
tests to determine if the FED's decision of quantitative easing ${ }^{5}$ brought serious macroeconomic consequenes in the developing countries (Sevinç et al, 2016: 84-85). In an integrated world, interest rates, which are the most basic determinatives of asset prices, are seen as the most attractive in examination rates and the most disputable in theory (Goldberg, Lothian and Okunev; 2003: 299).

In the next section we provide a short literature review of the impact of Fed policies on developing countries' interest rates and exchange rates. After that we test the impact of Fed interest rates using a vector auto regression (VAR) method to establish Granger causality between pairs of variables, studying the Fed funds rate, the CBRT interest rate on dollar-denominated deposits, the real exchange rate and the growth rate of Turkish GDP. We find that the Fed funds rate Granger-causes the domestic dollar rate and the real GDP growth rate. Real exchange rates Granger-cause real growth, but interest rate movements do not.

\section{LITERATURE REVIEW}

Especially, after 2008 Mortgage Crisis, Federal Bank went toward non-traditional policies (Quantitative Easing or QE) and tried to eliminate the effects of crisis via monetary expansion. As a result of monetary expansion made by Federal Bank, capital flow was observed to the developing countries. The FED by 2013 tried to exit QE and reduce the size of its balance sheet which led to capital outflow from the developing countries and fluctuations in the other macroeconomic variables. As shown in Table 1, this became a subject of serious study.

\section{TABLE 1. Literature Review}

\begin{tabular}{|c|c|c|c|c|c|}
\hline Authors & Period & Sample & Method & Variable & Conclusion \\
\hline $\begin{array}{l}\text { Seçme, } \\
\text { Hepşen. } \\
\text { (2018) }\end{array}$ & $\begin{array}{l}\text { 2002(M1)- } \\
\text { 2017(M2) }\end{array}$ & $\begin{array}{l}\text { USA, } \\
\text { TR, } \\
\text { GER, } \\
\text { HUNG, } \\
\text { POL. }\end{array}$ & $\begin{array}{l}\text { Bekk- } \\
\text { Garch }\end{array}$ & $\begin{array}{l}\text {-Turkish and US interest } \\
\text { rates, Turkish-US exchange } \\
\text { rate, and ISE100 }\end{array}$ & $\begin{array}{l}\text { The Fedl funder rate effects } \\
\text { short term rates in all } \\
\text { countries that except Hungary }\end{array}$ \\
\hline Kuzu (2017) & 2011-2017 & Turkey & Garch & $\begin{array}{l}\text {-CBRT average funding cost } \\
\text { (Independent) } \\
\text {-ISE100, } \\
\text {-ISE index of bank, } \\
\text {-nominal exchange rate } \\
\text { (dependent) }\end{array}$ & $\begin{array}{l}\text { Decisions of CBRT average } \\
\text { funding cost is directly } \\
\text { effects ISE100 and ISE } \\
\text { index of bank stocks, and } \\
\text { currency rate is affected } \\
\text { indirectly. }\end{array}$ \\
\hline $\begin{array}{l}\text { Sevinç, } \\
\text { Cergibozan, } \\
\text { Çevik. } \\
(2016)\end{array}$ & $\begin{array}{l}\text { 1988(Q1)- } \\
\text { 2015(Q3) }\end{array}$ & $\begin{array}{c}\text { Turkey, } \\
\text { USA }\end{array}$ & $\begin{array}{l}\text { Granger } \\
\text { Causality }\end{array}$ & $\begin{array}{c}\text {-Inflation, } \\
\text {-Unemployment, } \\
\text {-Real Gdp, } \\
\text {-Interbank overnight } \\
\text { borrowing interest }\end{array}$ & $\begin{array}{l}\text { While interest is dependent, } \\
\text { all other variables granger } \\
\text { cause interest. } \\
\text { Change in macroeconomic } \\
\text { variables and interest rate in } \\
\text { USA does Granger cause } \\
\text { interest rate in Turkey. }\end{array}$ \\
\hline $\begin{array}{l}\text { Erer, Çayır, } \\
\text { Erer, Altay. } \\
\quad(2016)\end{array}$ & $\begin{array}{l}\text { 1994(M1)- } \\
\text { 2014(M10) }\end{array}$ & $\begin{array}{l}\text { CBRT, } \\
\text { FED, } \\
\text { ECB. }\end{array}$ & Tvar & $\begin{array}{l}\text {-Short run interest rate } \\
\text { (Interbank), } \\
\text {-Industry production index, } \\
\text {-Inflation, } \\
\text {-R.E.C.R, } \\
\text {-Oil Price (Explanatory } \\
\text { variable) }\end{array}$ & $\begin{array}{c}\text { Fed fund rate interest } \\
\text { increases lead to capital } \\
\text { outflows., and appreciation } \\
\text { of currency rate. This } \\
\text { stimulates export and output } \\
\text { growth. }\end{array}$ \\
\hline
\end{tabular}

\footnotetext{
${ }^{5}$ Q.E. can be defined as purchase of borrowing instruments by central banks Borrowing instruments such as obligation and bond are bought by central banks and introduced into the market, and it created an expansionary effect (Fernandez, Bortz and Zeolla: 2018: 9).
} 


\section{Al-Farabi International Journal on Social Sciences}

\begin{tabular}{|c|c|c|c|c|c|c|}
\hline $\begin{array}{l}\text { Erer, } \\
\text { Güleç, } \\
\text { Erer, } \\
\text { Çelik. } \\
\text { (2015) }\end{array}$ & $2002-2014$ & $\begin{array}{l}\text { CBRT } \\
\text { FED } \\
\text { ECB }\end{array}$ & $\begin{array}{l}\text { Garch } \\
\text { Egarch } \\
\text { Tarch }\end{array}$ & \multicolumn{2}{|c|}{$\begin{array}{l}\text {-ISE100 1. Seance closing } \\
\text {-ISE100 2. Seance closing } \\
\text {-ISE100 changing for } 1 . \\
\text { Seance to } 2 \text {. Seance } \\
\text {-Dummy variable for } \\
\text { representing the decisions of } \\
\text { policy change } \\
\text {-Dummy variable for verbal } \\
\text { orientation }\end{array}$} & $\begin{array}{l}\text { If interest rate of policy } \\
\text { increase, fluctuation } \\
\text { decreasing on seance } \\
\text { While fluctuation increase on } \\
\text { first and second seance, has } \\
\text { been viewed that decreasing } \\
\text { daily fluctuation }\end{array}$ \\
\hline $\begin{array}{l}\text { Erer, } \\
\text { Çayir, } \\
\text { Erer, } \\
\text { Altay. } \\
\text { (2014) }\end{array}$ & $\begin{array}{l}\text { 2002(Q1)- } \\
\text { 2013(Q3) }\end{array}$ & $\begin{array}{l}\text { CBRT, } \\
\text { FED, } \\
\text { ECB. }\end{array}$ & $\begin{array}{l}\text { Markov } \\
\text { Switching }\end{array}$ & \multicolumn{2}{|c|}{$\begin{array}{l}\text {-Return on Assets } \\
\text {-Return on Equity } \\
\text { Monetary Policy interest rates } \\
\text { for Central banks of Turkey, } \\
\text { Europe and U.S. }\end{array}$} & $\begin{array}{l}\text { Throughout the Great } \\
\text { Recession, increase in FED, } \\
\text { CBRT and ECB interest rate } \\
\text { cuts reduced banking sector } \\
\text { returns. But in the prior } \\
\text { expansion lower interest rates } \\
\text { also had a negative effect on } \\
\text { banking sector profit. }\end{array}$ \\
\hline $\begin{array}{c}\text { Koepke. } \\
\text { (2018) }\end{array}$ & $2010-2013$ & $\begin{array}{l}\text { U.S.A. } \\
\text { E.M. }\end{array}$ & Panel & $\begin{array}{c}\text { Dependent } \\
\text {-Capital } \\
\text { movement }\end{array}$ & $\begin{array}{l}\text { Independent } \\
\text {-U.S. interest } \\
\text { rates } \\
\text {-Fed monetary } \\
\text { policy }\end{array}$ & $\begin{array}{l}\text { Capital movement depends } \\
\text { on U.S. interest rates. }\end{array}$ \\
\hline $\begin{array}{l}\text { Matousek, } \\
\text { Radic, } \\
\text { Akıncl, } \\
\text { Stewart. } \\
\text { (2013) }\end{array}$ & 1991-2007 & $\begin{array}{l}25 \text { com. } \\
\text { bank in } \\
\text { Turkey }\end{array}$ & $\begin{array}{l}\text { Pooled-Ols } \\
\text { (Panel) }\end{array}$ & \multicolumn{2}{|c|}{$\begin{array}{c}\text {-GDP Growth } \\
\text {-Capital Growth } \\
\text {-Bank credit Growth } \\
\text {-Inflation } \\
\text {-Bank size }\end{array}$} & $\begin{array}{l}\text { Capital and GDP growth has } \\
\text { a positive and significant } \\
\text { effect on bank credit growth } \\
\text { in long run. }\end{array}$ \\
\hline $\begin{array}{l}\text { Kashefi } \\
\text { (2008) }\end{array}$ & 1994-2006 & FED & Garch & $\begin{array}{l}\text { Dependent } \\
\text {-Stock } \\
\text { market } \\
\text { index }\end{array}$ & $\begin{array}{l}\frac{\text { Independent }}{\text {-Interest }} \\
\text {-Federal Fund } \\
\text { Rate }\end{array}$ & $\begin{array}{c}\text { A one percent decline in Fed } \\
\text { Funds interest rates leads to } \\
\text { an average increase between } \\
2.58-4.56 \% \text { on stock } \\
\text { market index. }\end{array}$ \\
\hline
\end{tabular}

Seçme and Hepşen (2018), in their studies, for USA, Hungary, Turkey, Germany, and Poland, made an econometric prediction by the method of Beckk-Garch Analysis between the years of 2002-2017 and, concluded that in the results obtained, all countries other than Hungary were affected by FED interest in the short term.

Sevinç, Cergibozan, Çevik (2016), in their studies, scrutinized macroeconomic variables between US and Turkey by means of Granger Causality Analysis and, in the model, where interest is dependent variables, it was concluded that it was the cause of the other variables.

Koepke (2018), in his panel data study, depending on the variations US interest rates, observed that portfolio movements in the emerging markets shifted to US.

\section{THE EFFECT OF FED ON THE DECISIONS OF CBRT, EXCHANGE RATE, AND GROWTH: GRANGER CAUSALITY ANALYSIS}

The aim of this study is to examine the relationship between interest rate and effective exchange rate and growth by Granger Causality Analysis in post-2003 period, as a result of the interest Federal 
Reserve System (FED) determined, by study of the interest rates the Central Bank of the Republic of Turkey applied to Dollar deposits. Following Sevinc, Cergibozan and Cevik (2016) we test our hypothesis using Granger Causality Analysis. We use quarterly data because monthly data did not exhibit statistical validity for the test we performed. We have 64 observations for the period of 2003:Q1 and 2018:Q4. The starting date is chosen because this is when the Turkish Republic passed to the regime of floating exchange rate.

The data of Real effective exchange and interest rate given to the Dollar deposits of CBRT were obtained the site of CBRT; the rates of Federal Reserve Rates, from FED Stats (FRED); and growth data, from TurkStat. Our analysis was made by means of Eviews 7.0 software.

\subsection{Setting Up Var Model}

Denoting quarterly interest data Central Bank of the Republic of Turkey gave to foreign currency deposits with MB; policy interest rate Federal Reserve System applied, FED; real effective exchange rate, RDK, and growth, G, VAR model, and including lagged dependent variables, was set up as follows.

$$
\begin{aligned}
& M B_{t}=c_{1}+\beta_{1: 1} M B_{t-1}+\cdots+\beta_{t-p} M B_{t-p}+\theta_{1.1} F E D_{t-1}+\cdots+\theta_{t-p} F E D_{t-p}+ \\
& \sigma_{1.1} R D K_{t-1}+\cdots+\sigma_{t-p} R D K_{t-p}+\delta_{1.1} G_{t-1}+\cdots+\delta_{t-p} G_{t-p}+\varepsilon_{t 1} \\
& F E D_{t}=c_{2}+\beta_{2,1} F E D_{t-1}+\cdots+\beta_{t-p} F E D_{t-p}+\theta_{2,1} M B_{t-1}+\cdots+\theta_{t-p} M B_{t-p}+ \\
& \sigma_{2,1} R D K_{t-1}+\cdots+\sigma_{t-p} R D K_{t-p}+\delta_{2,1} G_{t-1}+\cdots+\delta_{t-p} G_{t-p}+\varepsilon_{t 2} \\
& R D K_{t}=c_{3}+\beta_{3.1} R D K_{t-1}+\cdots+\beta_{t-p} R D K_{t-p}+\theta_{3.1} F E D_{t-1}+\cdots+\theta_{t-p} F E D_{t-p}+ \\
& \sigma_{3,1} M B_{t-1}+\cdots+\sigma_{t-p} M B_{t-p}+\delta_{3,1} G_{t-1}+\cdots+\delta_{t-p} G_{t-p}+\varepsilon_{t 3} \\
& 3 \\
& G_{t}=c_{4}+\beta_{4: 1} G_{t-1}+\cdots+\beta_{t-p} G_{t-p}+\theta_{4: 1} F E D_{t-1}+\cdots+\theta_{t-p} F E D_{t-p}+ \\
& \sigma_{4,1} M B_{t-1}+\cdots+\sigma_{t-p} M B_{t-p}+\delta_{4: 1} R D K_{t-1}+\cdots+\delta_{t-p} R D K_{t-p}+\varepsilon_{t 4}
\end{aligned}
$$

Seasonal adjustment was applied to all the data, denoted in Figure 1 by the variable name and_SA. As one can see the data behavior, particularly for the growth of Turkish GDP, changes significantly. 


\section{Al-Farabi International Journal on Social Sciences}

Figure 1: Seasonal Adjustment Of Data

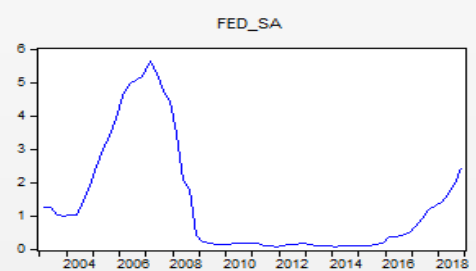

GRO_SA
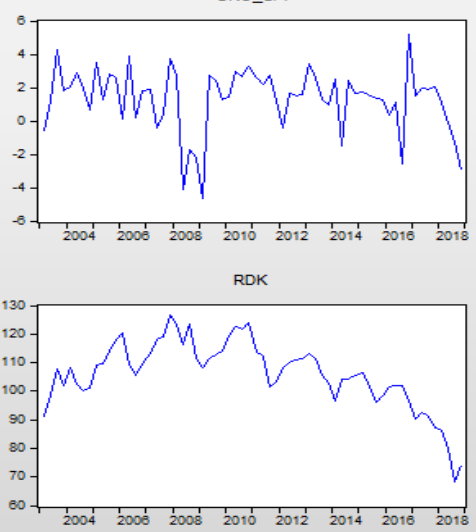

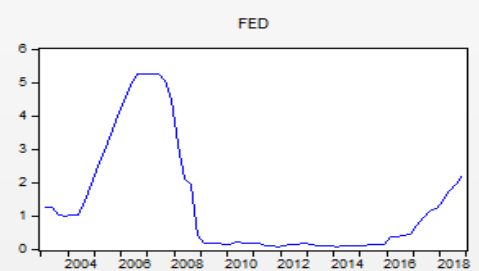

мв

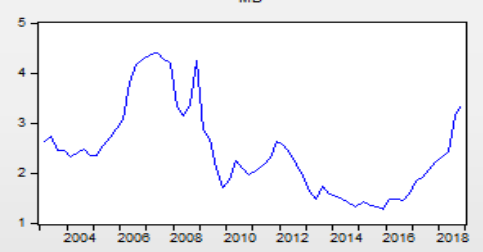

RDK_SA

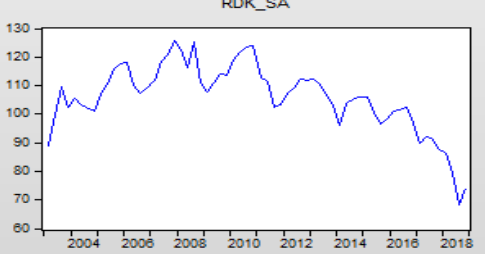

GRO

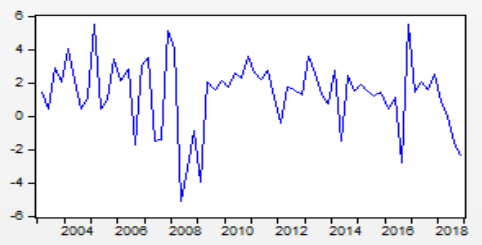

MB_SA

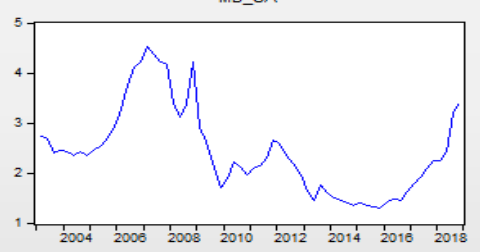

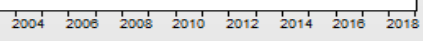

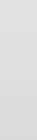

The data made free from causality were subjected to Unit Root Tests.

\subsection{Empirical Analysis}

After our variables are made free from seasonal effects, they were subjected to ADF Unit Root Tests. By means of VAR model set up in the light of the results obtained, lagging length was identified and whether or not there was an autocorrelation problem in these lagging length was searched. Analysis was continued with the lagging length selected. Testing the stability and normality of the model, additional lags were applied, and model was subjected to Toda-Yamamoto Test.

Table 1: Adf Unit Root Test

\begin{tabular}{|c|c|c|c|}
\hline VARIABLES & $\frac{\text { TREND AND }}{\text { INTERCEPT }}$ & INTERCEPT & $\underline{N O N E}$ \\
\hline FEDERAL FUND & $-3,577322(0.0404)$ & $\begin{array}{c}-3.127945 \\
(0.0297)\end{array}$ & $\begin{array}{c}-1.652607 \\
(0.0926)\end{array}$ \\
\hline GROWTH & $-6.313540(0.0000)$ & $\begin{array}{l}-6.228152 \\
(0.0000)\end{array}$ & $\begin{array}{c}-4.655916 \\
(0.0000)\end{array}$ \\
\hline$\frac{\text { CBRT INTEREST ON }}{\underline{\text { DEPOSIT }}}$ & $-0.843648(0.9555)$ & $\begin{array}{c}-1.212405 \\
(0.6641)\end{array}$ & $\begin{array}{c}-0.150946 \\
(0.6277)\end{array}$ \\
\hline$\frac{\Delta C B R T \text { INTEREST ON }}{\underline{D E P O S I T}}$ & $-6.426914(0.0000)$ & $\begin{array}{c}-6.408054 \\
(0.0000)\end{array}$ & $\begin{array}{c}-6.453242 \\
(0.0000)\end{array}$ \\
\hline$\underline{R E C R}$ & $-2.607761(0.2785)$ & $\begin{array}{c}-1.043220 \\
(0.7326)\end{array}$ & $\begin{array}{c}-0.457516 \\
(0.5130)\end{array}$ \\
\hline$\triangle R E C R$ & $-7.831722(0.0000)$ & $\begin{array}{c}-7.575891 \\
(0.0000)\end{array}$ & $\begin{array}{c}-7.591420 \\
(0.0000)\end{array}$ \\
\hline
\end{tabular}

NOTE:. The first values in the results of test represents t-statistics value and the value in parentheses, probability values.

ADF unit root tests showed that the CBRT Dollar Deposit rate and Real Effective Exchange Rate were not stationary in level. First difference of these two variables however were stationary. The Fed funds rate and the GDP growth rate were stationary in level form. To check our result, we tested all forms with a trend, without a trend, and without a constant. In all cases we concluded these two variables were stationary in their levels. 
Table 2: Lag Length

\begin{tabular}{|c|c|c|c|}
\hline LAG & AIC & SC & HQ \\
\hline $\mathbf{0}$ & 11,96671 & 12,11008 & 12,02243 \\
\hline $\mathbf{1}$ & 11,00549 & $11,72235\left(^{*}\right)$ & 11,28409 \\
\hline $\mathbf{2}$ & 10,51635 & 11,80669 & $11,01782\left(^{*}\right)$ \\
\hline $\mathbf{3}$ & 10,51875 & 12,38259 & 11,24310 \\
\hline $\mathbf{4}$ & 10,38651 & 12,82384 & 11,33374 \\
\hline $\mathbf{5}$ & $10,34388(*)$ & 13,35469 & 11,51399 \\
\hline $\mathbf{6}$ & 10,58423 & 14,16853 & 11,97721 \\
\hline
\end{tabular}

To determine lag length $p$ (in equations 1-4) we used a set of the Akaike Information Criterion (AIC), Schwarz Criterion (SC) and Hannah-Quinn Criterion (HQ) (Schwarz, 1978: 461-464; Hannan and Quinn, 1979: 190-195). The tests gave differing estimates of $q$ at 5, 1, and 2, respectively, as shown in Table 2. To gain better insight we used an autocorrelation (LM) test, results of which are in Table 3.

Table 3: Autocorrelation Lm Test

\begin{tabular}{|c|c|c|}
\hline LAGS & LM-STAT. & PROB. \\
\hline $\mathbf{1}$ & 33,35617 & 0,0066 \\
\hline $\mathbf{2}$ & 24,67099 & 0,0758 \\
\hline $\mathbf{3}$ & 32,43643 & 0,0088 \\
\hline $\mathbf{4}$ & 22,09532 & 0,1401 \\
\hline $\mathbf{5}$ & 16,99471 & 0,3859 \\
\hline $\mathbf{6}$ & 23,11643 & 0,1107 \\
\hline
\end{tabular}

The results showed that significant autocorrelation existed in the model at orders 1 and 2. This can influence the results of the SC and HQ tests. In contrast, at order 5, the lag length chosen by AIC, there is no issue with autocorrelation. Since AIC is more preferred in the small samples, our analysis will continue by setting $p=5$. And as can be seen by all roots of the AR process lying within the unit circle, we are surer that the VAR model is dynamically stable. 
Table 4: Ar Root Graphs

Inverse Roots of AR Characteristic Polynomial

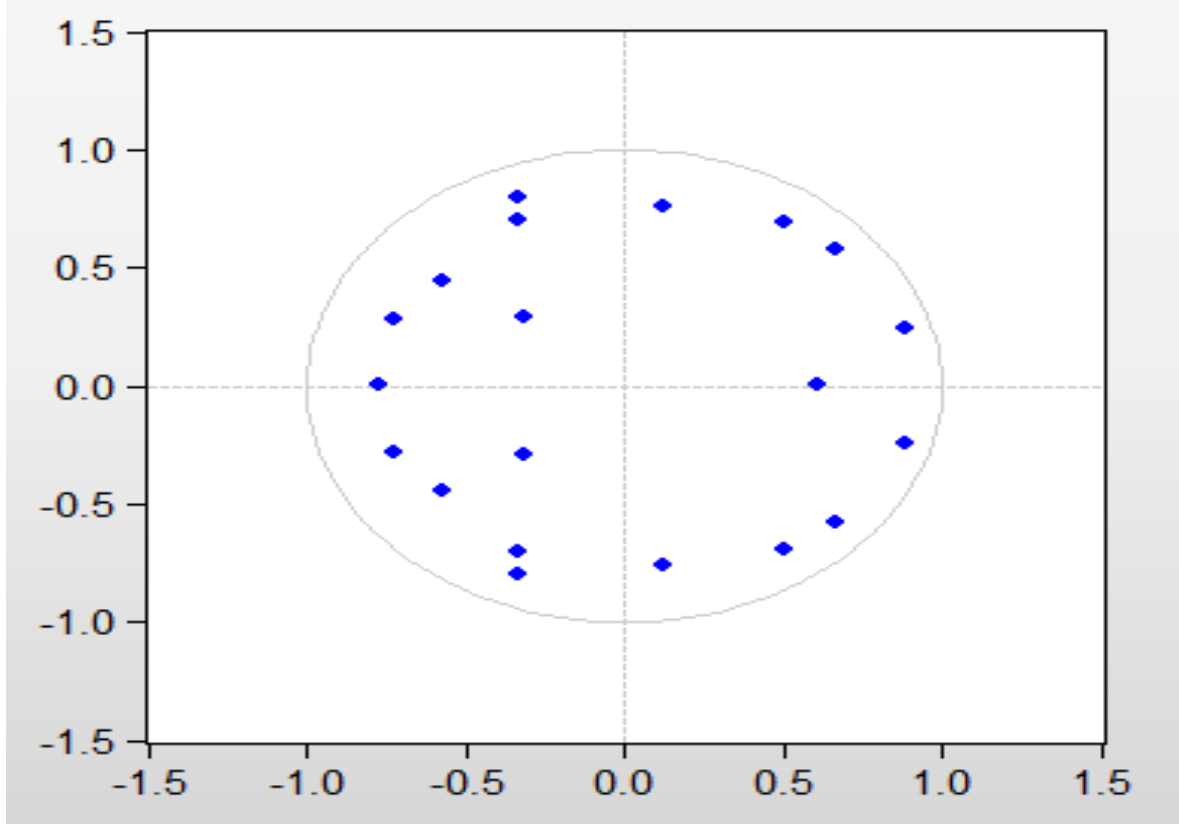

Table 5: Normality Test

\begin{tabular}{|c|c|c|c|}
\hline COMPONENT & JARQUE-BERA & DF & PROB. \\
\hline $\mathbf{1}$ & 2,641494 & 2 & 0,2669 \\
\hline $\mathbf{2}$ & 1,178674 & 2 & 0,5547 \\
\hline $\mathbf{3}$ & 4,176292 & 2 & 0,1239 \\
\hline $\mathbf{4}$ & 4,858734 & 2 & 0,0881 \\
\hline JOINT & 12,85519 & 8 & 0,1169 \\
\hline
\end{tabular}

The probability value of Jarque-Bera joint test was found 0.1169 . Since this value is bigger than $10 \%, \mathrm{H}_{0}$ Hypothesis was not rejected at the significance level of $10 \%$. Therefore, it was concluded that error terms were normally distributed.

Table 6: White Test

\begin{tabular}{|c|c|c|}
\hline CHI-SQUARE & Df & PROB. \\
\hline $\mathbf{3 8 6 , 5 8 3 0}$ & 400 & 0,6759 \\
\hline
\end{tabular}

White test presents a null hypothesis in the form of "There is no problem with heteroskedasticity". According to the results, statistical value of Chi-Square statistics was found 0.6759. Since null hypothesis is not rejected, it was seen that there was no problem with varying variance.

Finally, we test Granger causality using the Toda-Yamamoto test. The results appear in Table 7. Toda-Yamamoto show that this test is appropriate because our data did not turn out stationary at the level, due to the fact that Wald test will lose its validity, taking the additional laggings, they were subjected to Toda and Yamamoto Test (Toda and Yamamoto, 1995: 225-250). 
Table 7: Toda-Yamamoto Causality Test

\begin{tabular}{|c|c|c|c|}
\hline$\underline{\text { Ho }} \boldsymbol{\text { (Null) Hypothesis }}$ & $\underline{\text { CHI- }}$ & $\underline{\text { Df }}$ & $\underline{\text { PROB. }}$ \\
\hline CBRT INTEREST does not Granger cause RECR & 5,383983 & 5 & 0,3708 \\
\hline GROWTH does not Granger cause RECR & 2,223518 & 5 & 0,8174 \\
\hline FED FUND does not Granger cause RECR & 7,822855 & 5 & 0,1663 \\
\hline RECR does not Granger cause CBRT INTEREST & 4,639738 & 5 & 0,4614 \\
\hline GROWTH does not Granger cause CBRT INTEREST & 7,515557 & 5 & 0,1850 \\
\hline FED FUND does not Granger cause CBRT INTEREST & 19,38551 & 5 & 0,0016 \\
\hline RECR does not Granger cause GROWTH & 17,56139 & 5 & 0,0035 \\
\hline CBRT INTEREST does not Granger cause GROWTH & 6,334327 & 5 & 0,2750 \\
\hline FED FUND does not Granger cause GROWTH & 9,786200 & 5 & 0,0815 \\
\hline RECR does not Granger cause FED FUND & 6,220696 & 5 & 0,2853 \\
\hline CBRT INTEREST does not Granger cause FED FUND & 5,224159 & 5 & 0,3891 \\
\hline GROWTH does not Granger cause FED FUND & 6,358281 & 5 & 0,2729 \\
\hline
\end{tabular}

Some relationships therefore are supported by the Toda-Yamamoto causality tests. As we would expect in an open economy like Turkey's, the real exchange rate does cause GDP growth. And, supporting our main hypothesis, we reject the null hypothesis that the Federal funds rate of the US does not cause changes to the interest rate on dollar deposits in the Central Bank of Turkey. All other pair wise relationships fail to reject the null hypothesis of no Granger causality. Relationship between variable actualized as shown below.

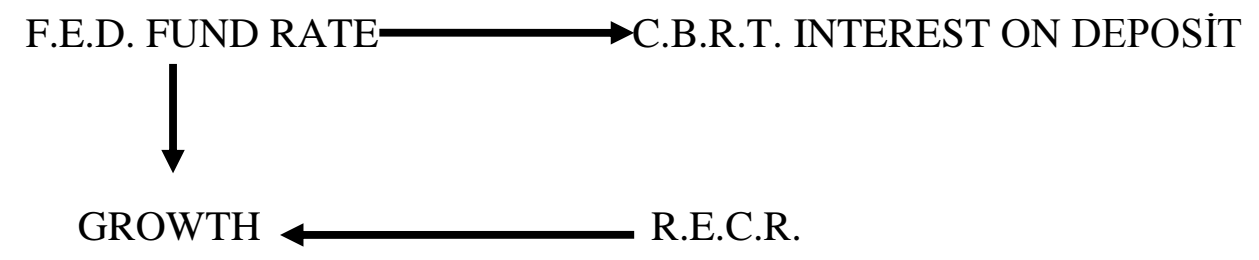

\section{CONCLUSION}

Our study finds a significant effect of the US Fed funds rate on dollar deposit rates at the Central Bank of Turkey. We believe these represent decisions made by investors allocating portfolios for dollar assets in the two countries. We use Granger causality tests to show that federal fund rates Granger cause of the dollar deposit rate and Turkish economic growth, while the real exchange rate between the two countries also Granger causes Turkish GDP growth. We found no evidence of Granger causality between the other variable pairs.

Importantly, we conclude that there was no effect of CBRT dollar deposit rates on the real exchange rate. This is evidence in favor of the hypothesis that U.S. monetary policy impacts the Turkish economy through its impact on the real exchange rate.

Especially after FED stops monetary expansion, the normalization of Federal Reserve monetary policy led to rates capital outflow from the developing countries. CBRT defended its exchange rate by changing its interest rates in the direction of FED decisions. Therefore, it is seen that FED decisions have a serious effect exchange rate and interest rates. 


\section{REFERENCES}

Akcay, Ü. and Güngen, A. R. (2019). The making of Turkey's 2018-2019 economic crisis, Working Paper, No. 120/2019, Hochschule für Wirtschaft und Recht Berlin, Institute for International Political Economy (IPE), Berlin. http://hdl.handle.net/10419/200182, last viewed 27 March 2020.

Bernanke, B. (2013). "Monetary Policy and the Global Economy," London: Speech to Department of Economics and STICERD (Suntory and Toyota International Centres for Economics and Related Disciplines) Public Discussion in Association with the Bank of England, London School of Economics, March 25. https://www.federalreserve.gov/newsevents/speech/bernanke20130325a.htm, last viewed 27 March 2020.

Çayır, M., Erer, D., Erer E. and Altay, N. O. (2014). TCMB, FED ve ECB Para Politikalarının Bankacılık Sektörü Performansı Üzerindeki Etkileri: Markov Switching Yaklaşımı: (2002-2013):18. Finans Sempozyumu, 15-18 October 2014, Denizli, Türkiye.

Çelik, Ş., Erer, D., Erer, E. and Güleç, T. C. (2015). TCMB Para Politikası Kararlarındaki Değişimlerin ve TCMB, FED ve ECB Sözlü Yönlendirmelerin BIST 100 Oynaklığı Üzerine Etkisinin Analizi (2002-2014). Maliye ve Finans Yazllarl 2015, 1(103), 51-84.

Ehrmann, M., Fratzscher, M., Rigobon, R. (2011). Stocks, Bonds, Money Markets And Exchange Rates: Measuring İnternational Financial Transmission. Journal of Applied Econometrics, 26(6), 948974.

Erer, E., Erer D., Çayır, M. and Altay, N. O. (2016). TCMB, FED ve ECB Para Politikalarının Türkiye Ekonomisi Üzerine Etkileri: 1994-2014 Dönemi Analizi. Sosyoekonomi Dergisi, 24(29), 285-305.

Fernandez, R., Bortz P. ve Zeolla N. (2018). The Politics of Quantitative Easing. Somo, ISBN: 97894-6207-132-2.

Fukuda, T. (2017). The Relationship Between Financial Development and Income Inequality in India: Evidence From Varx and Ardl Assessments. Asian Economic and Financial Review, 7(10), 10141027.

Gediz, D. and Sağın, A. (2015). Merkez Bankası Bağımsızlı̆̆ı Kavramı. İktisat Politikası Araştırmaları Dergisi, 2(2), 95-112.

Goldberg, L. G., Lothian, J. R., Okunev, J. (2003). Has International Financial İntegration İncreased?. Open Economies Review, 14(3), 299-317.

Hannan, E. J. and Quinn, B. G. (1979). The Determination Of The Order Of An Autoregression, Journal of the Royal Statistical Society, 41(2), 190-195.

Kashefi, J. (2008). The Effect of Changes in the Federal Funds Rate on Value and Growth Stock Prices: A Threshold GARCH Approach. International Research Journal of Finance and Economics 17, ISSN 1450-2887, 129-143.

Kuzu, S. (2017). Türkiye Cumhuriyeti Merkez Bankası (Tcmb) Faiz Koridoru Stratejisinin Hisse Senedi Piyasası Ve Döviz Kuru Üzerine Etkisinin Analiz Edilmesi. Uygulamalı Sosyal Bilimler Dergisi, 1(2), 46-61.

Koepke, R. (2018). Fed Policy Expectations and Portfolio Flows to Emerging Markets. Journal of International Financial Markets, Institutions \& Money, 55(1), 170-194.

Matousek R., Akinci A. D., Radic N. and Stewart C. (2013). Monetary policy and the banking sectorin Turkey. Journal of International Financial Markets, Institutions \& Money, 27(1), 269-285.

Obstfeld, M. and Taylor, A. M. (2003). Globalization and Capital Markets. Nber Working Paper, No 8846, 121-187. 
Pıçak, M. (2012). Faiz Olgununu İktisadi Düşünce Tarihindeki Gelişimi. Manas Sosyal Araştırmalar Dergisi, 1(4), 61-92.

Schmukler S. L. (2004). Financial Globalization: Gain And Pain For Developing Countries. Economic Review, 89(2), 39-66.

Schwarz, G. (1978). Estimating The Dimension Of A Model, The Annals of Statistics, 6(2), 461-464. Seçme, Z. O. and Hepşen, A. (2018). Amerikan Merkez Banaksı (FED) ve Avrupa Merkez Bankası (ECB) Kararlarının Finansal Piyasalara Etkisi. Uluslararası Toplum Araştırmaları Dergisi, 9(16), 1699-1732.

Sevinç, H., Cergibozan, R. ve Çevik, E. (2016). Fed'in Faiz Oranı Politikası ve TCMB'nin Politika Faizine Etkileri. Namık Kemal Üniversitesi Sosyal Bilimler Metinleri, 1, 71-87.

Shrestha, S. and McLean B. (2002). International Financial Liberalisation and Economic Growth. Economic Research Department Reserve Bank of Australia. Research Discussion Paper 2002-03.

Seyidoğlu, H. (2012). "Faiz (Interest)",

http://www.metinberber.com/kullanici_dosyalari/file/F.doc (Last Viewed: 03.05.2019).

Toda, H. Y. and Yamamoto, T. (1995). Statistical Inference In Vector Autoregressions With Possibly Integrated Processes, Journal of Econometrics, 66(1-2), 225-250. 